
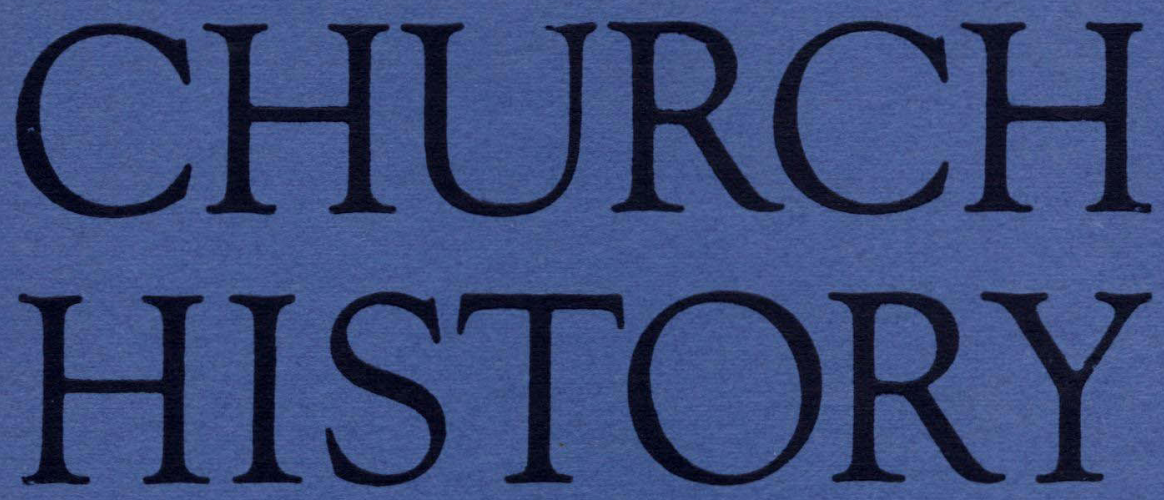

JUNE, 1969

Initial Byzantine Reactions to the Arab Conquest

Walter Emil Kaegi, Jr.

Some Aspects of the Influence of the Byzantine Maximos the Confessor on the Theology of East and West

Deno J. Geanakoplos

Justification and Eschatology in Luther's Thought

The Cult of the Royal Martyr

On Toleration in Massachusetts

George Wolfgang Forell

Common School, Common Religion? A Case Study in Church-State Relations, Cincinnati, 1869-70

Byron S. Stewart

E. Brooks Holifield

Robert Michaelsen

Anti-Christian Polemics in Seventeenth Century China

Douglas Lancashire

Review Articles:

The Early Church and the World

Robert M. Grant

The Creeds of Nicea and Constantinople Reexamined

David Larrimore Holland

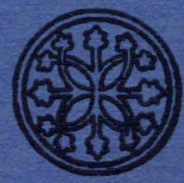

Published by

THE AMERICAN SOCIETY OF CHURCH HISTORY 
Founded By Philit Schaff, 1888: Reorganized, 1906; Incorporated By Act OF The Legislature of New York, 1916

\begin{tabular}{|c|c|}
\hline \multicolumn{2}{|c|}{ OFFICERS FOR 1969} \\
\hline $\begin{array}{l}\text { John Tracy Ellis ............. President } \\
\text { Robert M. Grant ..... Vice-President } \\
\text { James H. Smylie ….... Secretary } \\
\text { (Union Theological Seminary, Rich- } \\
\text { mond, Va.) }\end{array}$ & $\left.\begin{array}{l}\text { Stuart C. Henry ........ Asst. Secretary } \\
\text { Guy S. Klett .............. Treasurer } \\
\text { Robert M. Grant } \\
\text { Martin E. Marty } \\
\text { Jerald C. Brauer }\end{array}\right\} \quad \ldots$ \\
\hline $\begin{array}{l}\quad \text { VOTING MEMBERS } \\
\text { Carl Bangs } \\
\text { Richard M. Cameron } \\
\text { William A. Clebsch } \\
\text { Deno Geanakoplos } \\
\text { Robert M. Grant }\end{array}$ & $\begin{array}{l}\text { OF THE COUNCIL } \\
\text { George Mosse } \\
\text { Heiko A. Oberman } \\
\text { Albert C. Outler } \\
\text { Jaroslav Pelikan } \\
\text { John R. von Rohr } \\
\text { Elwyn A. Smith }\end{array}$ \\
\hline $\begin{array}{l}\qquad \text { OTHER MEMBERS } \\
\text { Winfred E. Garrison } \\
\text { John T. McNeill } \\
\text { Wilhelm Pauck } \\
\text { Charles Lyttle } \\
\text { Roland H. Bainton } \\
\text { E. R. Hardy, Jr. } \\
\text { Percy V. Norwood } \\
\text { Kenneth S. Latourette } \\
\text { Matthew Spinka } \\
\text { Cyril C. Richardson } \\
\text { Ernest G. Schweibert } \\
\text { Winthrop S. Hudson } \\
\text { Massey H. Shepherd }\end{array}$ & $\begin{array}{l}\text { OF THE COUNCIL } \\
\text { James Hastings Nichols } \\
\text { Ray C. Petry } \\
\text { Sandford Fleming } \\
\text { Sidney E. Mead } \\
\text { Carl E. Schneider } \\
\text { Leonard J. Trinterud } \\
\text { Quirinus Breen } \\
\text { H. Shelton Smith } \\
\text { George H. Williams } \\
\text { Robert T. Handy } \\
\text { Jerald C. Brauer } \\
\text { Harold J. Grimm } \\
\text { Lefferts A. Loetscher }\end{array}$ \\
\hline
\end{tabular}

Subscription prices are ten dollars a year, two dollars and seventy-five cents for single copies. Twenty-five cents a year should be added for foreign countries. Remittances should be made to the order of the order of the American Society of Church History. Subscriptions, renewals, changes of address, claims for missing numbers, orders for single copies of current or back issues should be addressed to Guy S. Klett, 321 Mill Road, Oreland, Pennsylvania. Claims for missing numbers will be honored without charge if made within two months following the regular month of publication

Microfilm reproductions of the American Society of Church History Papers, series one and two, and of Church History, volumes I-XVII (1932-1948) are available at cost ( $\$ 22$ and $\$ 39$, respectively, plus transportation) from the ATLA Board of Microtext. Orders should be sent to Raymond P. Morris, Library of the Yale Divinity School, 409 Prospect Street, New Haven 11, Connecticut, as well as inquiries as to microfilm portions, Xerox copies.

Microfilm reproductions of Church History beginning with Volume XVIII are available to subscribers and to members of the Society from University Microfilms, 313 North First Street, Ann Arbor, Michigan.

A cumulative Index of both series of Papers and of Church History through volume XXX (1961) is available at two dollars a copy from Guy S. Klett, 321 Mill Road, Oreland, Pennsylvania.

Publication office is Berne, Indiana 46711

Second-class postage paid at Berne, Indiana 46711.

Send change of address and Forms 3579 to 321 Mill Road, Oreland, Pennsylvania 19075.

Manuscripts and books for review should be sent to the editorial office, Swift

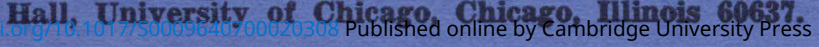




\section{CHURCH HISTORY}

Edited by

Robert M. Grant, Martin E. Marty, Jerald C. Brauer with the cooperation of

R. Pierce Beaver (Divinity School, University of Chicago)

Robert T. Handy (Union Theological Seminary)

E. R. HARdY, JR. (Berkeley Divinity School)

Winthrop S. Hudson (ColgateRochester Divinity School)
James H. Nichols (Princeton Theological Seminary)

Jaroslay Pelikan (Divinity School, Yale University)

Ray C. Petry (Divinity School, Duke University)

LeOnard J. Trinterud (San Francisco Theological Seminary)

George H. Williams (Divinity School, Harvard University)

Editorial Assistant: LARRY J. Alderin K

\begin{tabular}{lll}
\hline VOL. XXXVIII & JUNE, 1969 & NO. 2 \\
\hline
\end{tabular}

\section{TABLE OF CONTENTS}

Initial Byzantine Reactions to the Arab Conquest

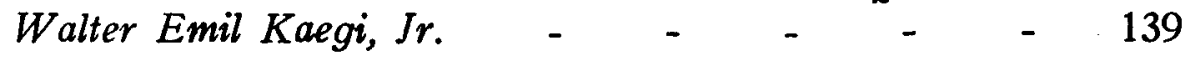

Some Aspects of the Influence of the Byzantine

Maximos the Confessor on the Theology OF EAST AND WeST

Deno J. Geanakopolos - $\quad$ - $\quad$ - $\quad$ - $\quad$ - 150

Justification and Eschatology in LUther's Thought

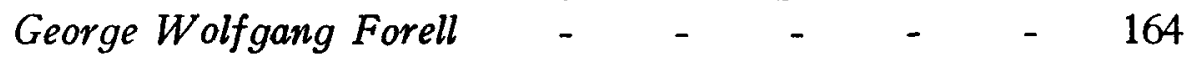

The Cult of the Royal Martyr

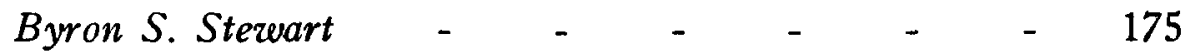

On Toleration in Massachusetts

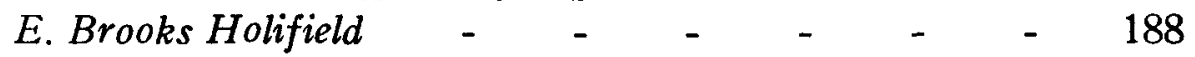

Common School, Common Religion? A Case Study in

Church-State Relations, Cincinnati, 1869-79

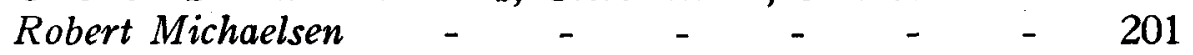

Anti-Christion Polemics in Seventeenth Century China

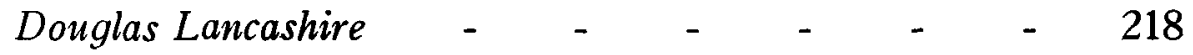

Review Articles:

The Early Church and the World

Robert M. Grant

The Creeds of Nicea and Constantinople Reexamined

David Larrimore Holland

(C) 1969 by American Society of Church History 


\section{CONTENTS}

Book Reviews

BRAND, C. E.: Roman Military Law Robert M. Grant

Snyder, Graydon F.: The Shepherd of Hermas E. R. Hardy

Riley-Smith, Jonathan: The Knights of St. John in Jerusalem and Cyprus Walter Emil Kaegi, Jr.

Pritchard, V.: English Medieval Graffiti John Phillips

Logan, F. Donald: Excommunication and the Secular Arm in Medieval England Rhys W. Hays

LEwIs, P. S., : Later Medieval France, The Polity David C. Steinmetz

Southern, R. W., ed.: Essays in Medieval History Walter Emil Kaegi, Jr. Genicot, LÉopold: Contours of the Middle Ages K. F. Morrison Schwonbel, Robert: The Shadow of the Crescent .... Walter Emil Kaegi, Jr.

Solari, Giovanna R., and Tuten, Frederic: The House of Farnese Bernerd C. Weber

Clark, Francis: Eucharistic Sacrifice and the Reformation John R. Meyer

KISch, GuIDo: Melanchthons Rechts-und Soziallehre .... Clyde L. Manschreck Fraenkel, Peter, and Greschat, Martin : Zwanzig Jahre Melanchthonforschung Hans J. Hillerbrand

Simon, Edith : Luther Alive J. R. Tinsley

McDonnell, Kilian: John Calvin, the Church and the Eucharist

B. A. Gerrish

RIDLEY, JASPER : John Knox John T. McNeill

Mellor, Alec: Histoire de l'anticléricalisme Norman Ravitch Hodgson, Peter C. : The Formation of Historical Theology B. A. Gerrish

GLICK, G. WAYNE: The Reality of Christianity B. A. Gerrish

Pauck, Wilhelm : Harnack and Troeltsch Van A. Harvey

Condon, Thомas J.: New York Beginnings George L. Smith

Drury, Clifford M., ed. : First White Women Over the Rockies

Robert H. Keller

Stroyen, William B.: Communist Russia and the Russian Orthodox Church, 1943-1962

Matthew Spinka

Nichols, James Hastings Corporate Worship in the Reformed Tradition Horton Davies

Stark, Werner : The Sociology of Religion: A Study of Christendom Franklin Sherman

Bennett, John W.: Hutterian Brethren Cornelius J. Dyck 